Conference Paper

\title{
Towards Clean River Through Distributed Community Based Waste to En- ergy
}

\author{
Supriadi Legino ${ }^{1}$, Doddy Hertanto ${ }^{2}$, Hany Stenvil ${ }^{3}$, Aria Aditya ${ }^{2 *}$ \\ ${ }^{1}$ Chief and Founder, hC-Triple Helix Academy \\ ${ }^{2}$ Marketing Department, PT Hexa Integra Electrica \\ ${ }^{3}$ Renewable Energy Department staff, PT Hexa Integra Electrica
}

${ }^{*}$ Corresponding author:

E-mail: aria.supriadi@hire.co.id

\begin{abstract}
Municipal waste is the main source of challenges to ensure a clean river, with the main cause being a lot of its citizens still throw their plastic bags full of waste into the river, as if the river is a public moving garbage container. The purpose of this study is to conduct a benefit-cost analysis of applying the new way of community-based waste treatment (CBWT) that has been successfully applied as a pilot project at various places including the office area of Gerakan Ciliwung Bersih (GCB). The research is a case study analysis method based on real data taken from the ongoing CBWT units that can convert a ton of waste into approximately $300 \mathrm{~kg}$ of pellet with around 3,000 kCal $/ \mathrm{kg}$ bio-coal using microbiological treatment. The case studies in more than 15 places revealed that the capital expenditure of CBWT is around IDR 497,200, 000 and its operational expenditure is IDR $280,970,000$ may potentially be profitable to attract small businesses that run these CBWT services. The proposition of this study is the more CBWT business units, the cleaner the river will be and in addition, it will also give social and environmental benefit as it will create employment opportunities and reducing Green House Gasses In this study, the financial, social, and environmental aspects will be calculated by using simulation.
\end{abstract}

Keywords: Municipal Waste, Green House Gasses (GHG), Community-Based, Bio-logical treatment,

\section{Introduction}

The need for safe drinking water and clean water is very important for humans. In the Environmental Pillar of the Sustainable Development Goals (TPB), the fulfillment of the water right is outlined in the sixth goal, namely "ensuring the availability and management of clean water and proper sanitation". The right to water is included in the United Nations Declaration on Human Rights to Water (United Nations Declaration of Human Rights to Water) and the 1945 Constitution Article 33 paragraph 3 . The vital function of water requires proper maintenance to remain viable and useful.

Increased population growth and economic acceleration have an impact on inland waters (rivers). High population growth and density are closely related to the rate of clean water demand in a region. This of course has implications for access to clean water. The population dynamics affect ecosystems, including those related to water availability. Pollution and changes in habitat around the waters cause damage to the ecosystem (Fei et al., 2018).

The environmental pollution of rivers in Indonesia is increasingly worrying. Based on the Central Statistics Agency Report (2019), the quality of water in Indonesia is still not very good, where out of 98 rivers in Indonesia, 54 rivers are mildly polluted, 6 rivers are moderately polluted, and 38 rivers are light-polluted. This situation is worse than the previous year in 2018 , namely, of the 
97 rivers in Indonesia, 67 rivers are lightly polluted, 5 are light-polluted, and 25 are light-heavily polluted. Rivers have many benefits to human life, including drinking water, agriculture, promoting fishery operations, recreation, and transportation, all of which are essential in rivers (Central Statistics Agency, 2019).

Indonesia is ranked second as a contributor to plastic waste in the sea. The river plays an important role in this negative achievement because it is one of the main routes for entry by land to the sea. Awareness is needed to improve the situation (Sucahyo, 2019). Indonesia's rivers and gutters are clogged with bottles, bags, and another plastic packaging. The population explosion, among others, has an impact on the spread of containers, wrappers, and plastic bags that replace natural and traditional packaging which is easily biodegradable, such as banana leaves. As a result, efforts by local governments to collect and manage waste have been unable to keep up with the dramatic expansion of citizen-generated waste.

As reported by National Waste Management Information System (n.d.), there is more than $46 \%$ of unmanaged waste from the annual 36.7 million municipal waste, recorded from 291 cities and other districts. 2020, national performance to manage municipal waste is still $53.2 \%$ by 15.86 waste reduction and $37.34 \%$ treated. Not all wastes can be put or transported to the landfill and the fact is that people throw the remaining waste into public areas including rivers, roads, gardens, and open spaces. Prof. Enri Damanhuri asserts that commonly among those of unmanaged waste, $51.4 \%$ of wastes are burned, $6,78 \%$ are thrown into the water channel, river, or sea, and $2,7 \%$ are throwed somewhere. He asserts further that the current practice is, all collected municipal waste is put into the closer temporary waste areas (TPS) for several days until the waste trucks transport it to the landfill site.

River waste is getting more problematic as people inevitably use to throw their waste in public areas including rivers due to the limited capacity of landfills and the government-less ability to transport the whole waste into the landfill. On the other hand, a landfill in most big cities has already exceeded its capacity, while a government effort of acceleration program (Presidential Regulation no. 35/2018) to solve municipal waste problems for 12 cities is getting a serious sleeping as only one city of Surabaya that could accomplish the project (Legino, 2020)=

Therefore, a paradigm shift is required from the old mindset that waste treatment is a centralized government obligation to the new one that waste treatment obligation should be distributed to every community as the waste source. If the government does not change the way to clean waste from rivers by merely picking up waste from the rivers, then the problem of river waste will never be ended. This conventional practice should be changed by treating the waste at its source to minimize the number of waste throwing into the rivers. Waste treatment at its source is already promoted by the so-called 3R (reduce, reuse recycle) program and the establishment of "Bank Sampah" as collectors and sellers of valuable wastes such as bottles, cans, and corrugated paper-(Tata Kelola Persampahan di Indonesia, 2021).

The case studies of waste treatment by communities in various areas can be used to propose a new paradigm of distributed waste treatment at its sources, except for a larger size, metal, electronics, and dangerous wastes. This study will simulate the cost and benefit of the proposed paradigm shift by a gradually decreasing portion of waste to landfill and increasing the number of distributed waste treatment units using the biological treatment waste to energy solution as will be discussed in the section of the case study description. This study aims at providing academic support to the idea that community-based waste treatment (CBWT) that will be elaborated in the next section as waste processing at its source is more beneficial than a conventional landfill waste model. A benefit-cost simulation will be used to compare the cost and benefit between the two ways of paradigm. The setting or unit analysis is the Ciliwung rivers that are impacted by the waste from the city of Jakarta other cities were passing by the Ciliwung Rivers. The amount of waste for simulation analysis is limited to the non-toxic municipal waste using the data taken from the previous case studies. 


\section{Literature Review \\ Mechanical Biological treatment}

The proposed CBWT model is a type of mechanical-biological treatment (MBT), which has been used in some countries to treat residual municipal solid waste to improve waste treatment at landfills. The result of a study in Rio de Janeiro Brazil reported that after MBT, most of the organic content that harmed the environment including organic carbon, nitrogen in the leachate, and the gas production rate are reduced lower than $90 \%$ from the untreated waste. It may also decrease up to $70 \%$ of the size of the material to be disposed of in landfills. This study also depicted that this effort can minimize the landfill monitoring work as well as utilizing the stabilized material for other purposes such as reforestation and energy use (Munnich K et.al., 2006).

A common method of MBT by aerobic decomposition is biodrying, to dry and partially stabilize residual municipal waste. Different form of composting, drying is attempting to dry and preserve most of biomass content of the waste matrix, rather than fully stabilize it. A high-quality solid recovered fuel (SRF) of biomass can be attained by biodrying. It is reported that the time required to complete the cycle process is within 7-15 days, with mostly can reduce around $25-30 \%$ of $\mathrm{H} 20$ and CO2, resulting in moisture contents of less than $20 \%$ (Velis et.al., 2099). In another study, the effect of biodrying process on municipal solid waste (MSW) showed that the water content of waste can be reduced and increased a net heating value (NHV) $41 \%$ higher than untreated waste to $16,779 \pm 2,074 \mathrm{~kJ} \mathrm{~kg}-1$ wet weight (Tambone et.al., 2011)

One study conducted a laboratory test of biodrying process of the mixed municipal solid waste with an initial moisture content of $61.25 \%$ and the aerobic reactor was fed with $109 \mathrm{~kg}$ of this substrate, with the self-heating inside reactor matrix was assumed in the range of $50-60{ }^{\circ} \mathrm{C}$ during the design stage. The results showed that after four days experiment, the temperature inside the reactor was rising to a peak value of $59{ }^{\circ} \mathrm{C}$, with a reduction of $56.5 \%$ of volume, and an increase of $52 \%$ of bulk density of the substrate at the end of 33 days of biodrying. Also, the weight of mixed MSW substrate has been reduced by $33.94 \%$ in 20 days of reaction and the average moisture reduction of the matrix was $20.81 \%$ (reduced from the initial value of $61.25 \%$ to the final value of $48.5 \%$ ). The leachate production has been eliminated (Tom et.al, 2016)

\section{Community-Based Waste Treatment (CBWT)}

Community-Based Waste Treatment (CBWT) is a localized waste processing activity at communities as the sources of wastes, as an alternate of centralized processing at the landfill. Until currently, the common practices of CWBT that are supported by the Indonesian Government include Reduce, Reuse, Recycle (3R), and collecting valuable waste and composting fertilizer thru the Bank of Waste (Raharjo et al, 2016; Kholil at al., 2018). However, the end product of CBWT that will be discussed in this study is energy in terms of biocoal, which is adopted from the idea of Local waste processing unit, namely TOSS, a brand name like another brand name KAIZEN, or OZAKI from Japan. TOSS is the Indonesian language abbreviation stands for local waste management, which means Local Waste Processing Unit, which idea is to solve a huge amount of waste by simultaneously empowering a large number of communities to treat waste at its source rather than at landfill (Legino, 2019).

CBWT by using the TOSS model is a biological treatment that combines several processes including probiotic, composting, fermenting, and biochemical, which translates into waste treatment at its source, can convert a ton of waste into approximately $300 \mathrm{~kg}$ of pellet with around 3,000 kCal/kg bio-coal, in less than a week (Legino, 2017, Solving, Simulation); (Legino, 2019, Attaintment, Waste); (Legino, 2019, Reducing); (Legino, 2019, Listrik Kerakyatan). Since January 2018, TOSS has been implemented at Klungkung District followed by other locations in Bali, Jakarta, Lombok, South Kalimantan, Bandung, Jepara, Tegal, and Jakarta. Compare to other wasteto-energy models, TOSS offers many benefits include eliminating waste truck traffic because TOSS 
can solve the waste problem locally at its sources of waste or local, no need for organic-non organic presorting work.

The result of TOSS pilot projects as described above shows that TOSS as CBWT has been successfully made briquette or pellet from fresh municipal waste in less than 10 days. The process of TOSS as CBWT is using a biological treatment that can convert municipal waste into fuel in terms of briquette or pellet as biocoal. The process is an aerobic process conducted by the battery, which is created through bio activator inside the bamboo box media, that takes around 10 days to reduce the moisture content, eliminate odor, and increase the calorific value of waste (e.g. Legino, 2019; Supriadi et al., 2019; Legino, 2020).

\section{The advantages of TOSS as CBWT}

Legino (2019) asserted that unlike conventional waste to energy (WtE) that needs landfill, TOSS needs no landfill because waste is processed at its source and it can be installed in every community that produces waste as small as 3 ton per day with the investment less than USD 20,000 (including Civil work). Unlike conventional waste-to-energy projects that are owned by a large investor, TOSS can be owned and managed by local people using their land. TOSS is much simpler in processing compare to the conventional waste treatment that needs segregation of waste, TOSS needs no initial sorting of waste. Lastly, unlike wood forest and another agricultural biomass pellet that needs large land and several months or years for harvesting waste is produced every day and takes only a week to become biocoal pellet (Legino et al., 2017; Legino et.al., 2019).

\section{TOSS processing activities from waste to biocoal pellet}

TOSS can be categorized as the MBT method since its process begins by a microbiological process including deodorizing (probiotic), composting (thermophilic decomposition; pathogen elimination), fermenting (composting of protein; metal-binding), the biochemical-biophysical process to increase calory. The waste will be dry and odorless after about 5 to 7 days and then followed by Mechanical processing to make the size homeland and to increase density. The biological process increases the energy because the microbe used in the TOSS process can produce bio-hydrogen as the main energy of the TOSS product, which energy is 3 times stronger than that of Carbon. In addition, bio-hydrogen is denser and more environmentally friendly as the end product is water H2O (Legino et al., 2019, Listrik Kerakyatan; Velis et al., 2009).

As seen in Figure 4, the TOSS process to convert waste to biocoal pellets is as follows: 1). Assemble a bamboo box with an of $2 \mathrm{~m} \times 1,25 \mathrm{~m} \times 1,25 \mathrm{~m}$ (as a measure of around 1 ton of fresh waste); 2) After mineral water bottle and other valuable waste are taken out, but the fresh waste into the bamboo box; 3) Spray the waste with bio activator, with the amount of 1 liter mixed with 40-liter water (sufficient for 1 ton of waste) layer by layer with the same process until the container is full with; 4) Generally the waste which is already fermented will lose its smell after 3 days; 5) Leave the process until 5 days until the waste dry and its volume decrease by one third; 6) the waste is ready to be chopped and pressed into pellets. It requires 5 five bamboo containers to do five cycles of TOSS processing, the equivalent of 3-ton waste per day. After one day, the bacteria will work and waste becomes hot and it needs to be monitored to keep the temperature less than 60-degree Celsius so that the bacteria is not dead. After around 9 months of waste processing with TOSS at the landfill of Sente, Klungkung, the landfill becomes clean and flat as shown in 7) Messy landfill at Sente Klungkung before TOSS implementation, and 8) Clean and flat landfill at Sente Klungkung 9 months after TOSS implementation (Supriadi et al., 2019) 


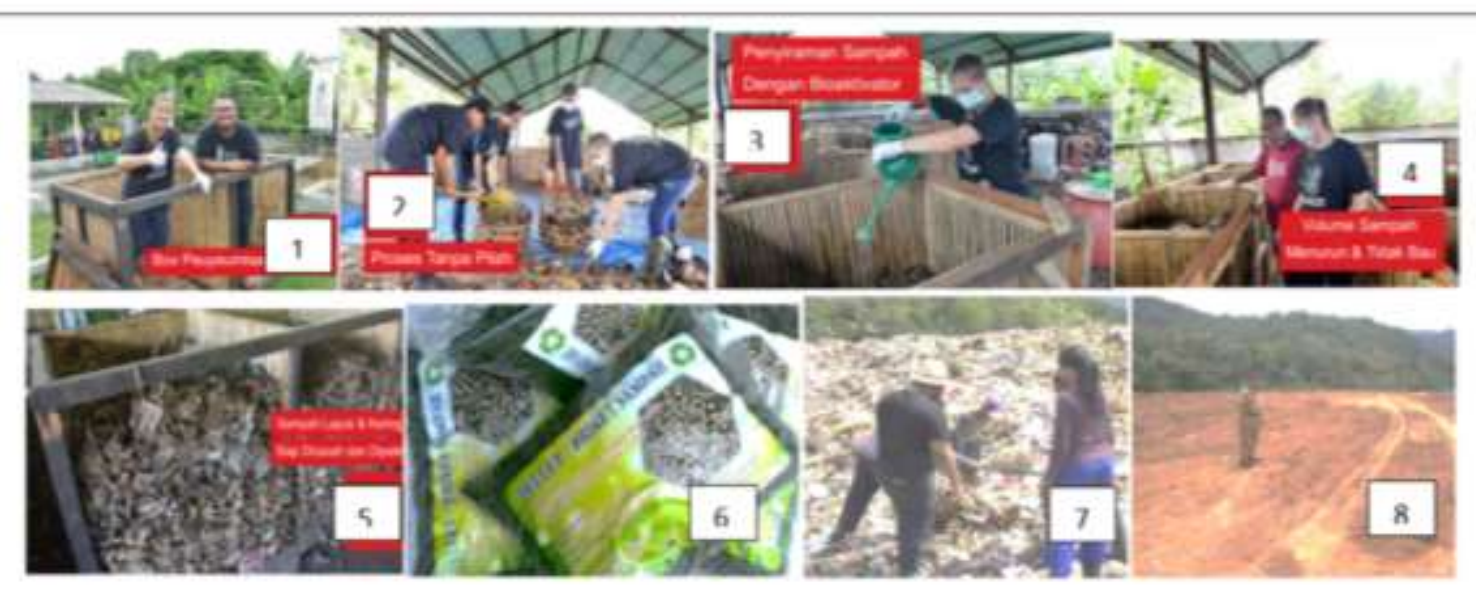

Figure 1. Klungkung case showing TOSS processing activities and the clean landfill

\section{Green House Gasses (GHG) Compensation for CBWT instead of Landfill.}

CBWT TOSS may potentially get double compensation of carbon emission reduction, firstly from avoiding waste to landfill and secondly from using the waste biocoal to substitute coal as fossil fuel. Climate mitigation in terms of ton $\mathrm{CO}_{2 \mathrm{e}}$ will be predicted using the GHG equivalencies calculator from EPA (Environmental Protection Agency) USA, as follows. It has been reported in various published journals regarding TOSS, that any ton of waste can produce around $300 \mathrm{kWh}$ electricity and the average calorific value of waste bio-coal is around $3000+/-200 \mathrm{kCal} / \mathrm{kg}$. In this study, since the TOSS method avoids waste going to landfill areas, so it is assumed that TOSS will have a similar impact on greenhouse gasses reduction as that of recycled waste.

EPA has developed Waste Reduction Model (WARM), following a life-cycle assessment methodology by estimation techniques for greenhouse gas emissions inventory. According to WARM, the net emission reduction from recycling mixed recyclables (e.g., paper, metals, plastics), compared with a baseline in which the materials are landfilled (i.e., accounting for the avoided emissions from landfilling), is 2.94 metric tons of carbon dioxide equivalent per short ton (EPA,2019).

EPA reported that the average carbon coefficient of coal combustion for electricity generation in 2018 was 26.09 kilograms carbon per mmbtu with100 percent fraction oxidized (EPA,2020). Carbon dioxide emissions per pound of coal were $44 / 12$, calculated by multiplying heat content times the carbon coefficient times the fraction oxidized times the ratio of the molecular weight of carbon dioxide to that of carbon. For example, $20.85 \mathrm{mmbtu} /$ metric ton coal $\times 26.09 \mathrm{~kg} \mathrm{C} / \mathrm{mmbtu}$ $\times 44 \mathrm{~kg} \mathrm{CO}{ }_{2} / 12 \mathrm{~kg} \mathrm{C} \times 1$ metric ton coal/2,204.6 pound of coal $\times 1$ metrc ton/1,000 kg $=9.05 \times 10^{-}$ ${ }^{4}$ metric tons $\mathrm{CO}_{2} /$ pound of coal $=2.02$ metric tons $\mathrm{CO}_{2} /$ ton of coal.

\section{Methods}

Type of Study

This study method is a qualitative research based on the author's own worldviews paradigm or set of beliefs to the research project. This qualitative inquiry is conducted using the methodology of case study that explores a case over time through detailed, in-depth data collection involving multiple sources of information such as observation and documents and reports a case description and case-based themes. The case studies are based on the pilot projects and implementation of the TOSS method as a waste treatment by communities that had been conducted in various areas. The study proposes that the TOSS model as distributed waste treatment at its sources can be used to reduce the waste throwing into the river, in this context, Ciliwung River, which is passing Jakarta city. 


\section{Data analysis}

The case studies and the previously reported results will be used to answer the research question and the analysis method would base on real data taken from the real cases of applying CBWT pilot projects and implementation in more than 15 places, where there is intension from the sponsors to conduct the pilot project of CBWT. The sponsors include the local governments, the CoalFired Power Plant authority, and any other government and private parties as shown in figure 3. In all cases, the results show that CBWT is a relatively easy way that could be run by local people using locally made equipment. The proposed CBWT is a biological treatment, called "TOSS", the abbreviation of Tempat Olah Sampah di Sumber, which translates into waste treatment at its source, can convert a ton of waste into approximately $300 \mathrm{~kg}$ of pellet with around 3,000 kCal/kg bio-coal, in less than a week (Legino, 2017, Solving, Simulation); (Legino, 2019, Attaintment, Waste).

In this study, the financial, social, and environmental aspects will be calculated using simulation, the result of which can be used for the pre-feasibility study of the municipal waste solution, related to the cleaner river program. As seen in Figure 2, the waste process flow begins from the city population $(\mathrm{P})$ that will be assumed to produce a specific number of waste $\left(\mathrm{W}_{\mathrm{m}}\right)$. A big portion of various wastes are transported to the landfill site $\left(\mathbf{W}_{\mathbf{L}}\right)$, some portions of the waste are treated at its sources through the $3 \mathrm{R}$ program $\left(\mathbf{W}_{\mathbf{s}}\right)$, some are thrown into the river $\left(\mathbf{W}_{\mathbf{R}}\right)$ and the rest are scattered to other places including public spaces $\left(\mathbf{W}_{\mathbf{0}}\right)$

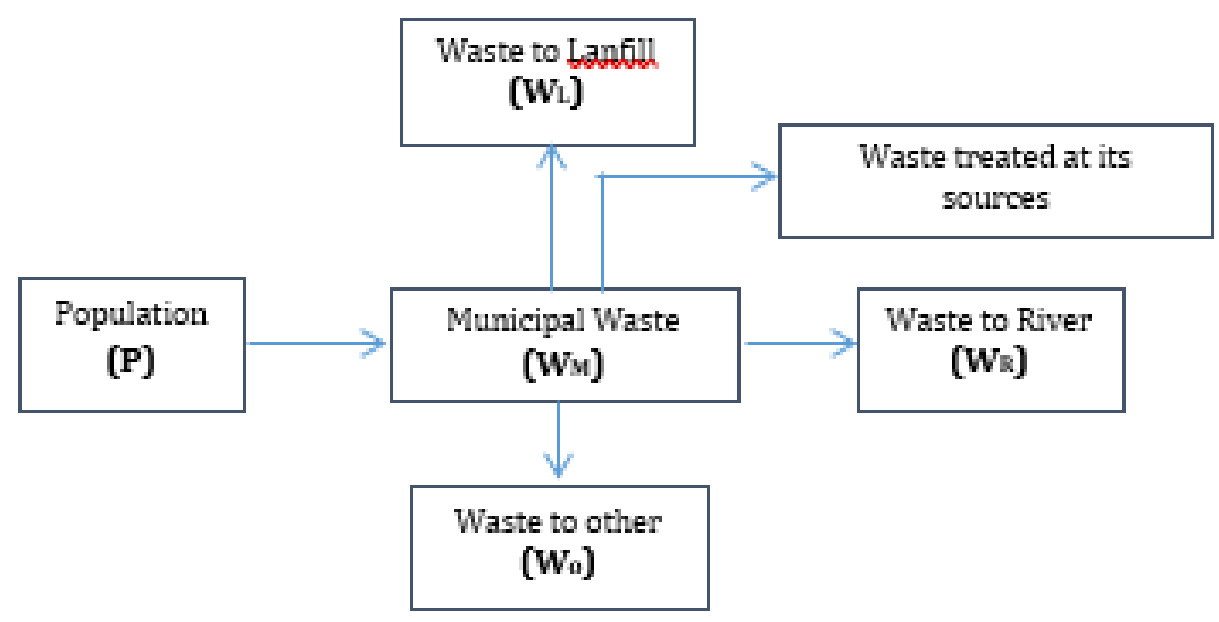

Figure 2. Waste volume distribution portion model

To minimize the number of wastes in the river $\left(\mathbf{W}_{\mathbf{p}}\right)$, this study proposes a new model of a Community Based Waste Treatment (CBWT) with the basic idea that there will be a minimum portion of waste entering the river if people can treat waste in their communities. This new paradigm model is shown in Figure 3, which shows Biocoal (B) as the end product of the waste treatment. Under the new paradigm, most wastes are treated in communities to minimize the portion of waste going into the landfill, river, as well as other public places. How long will it takes to make the river clean by solving the waste problem at its sources will depend on the financial affordability to build as many as CBWT units along the river riparian and other plants scattered across the city. For the simulation in this study, the city of Jakarta and the available data and several numbers of assumptions will be used to illustrate the model. 


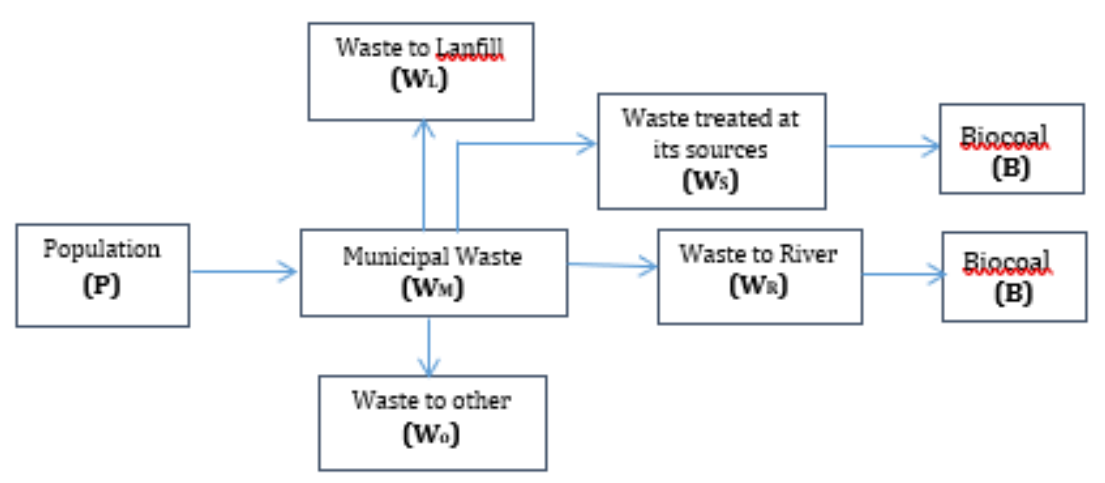

Figure 3. The flow of waste to biocoal process

\section{Case study description}

Pilot projects and Implementation of TOSS

TOSS as the proposed solution is a simple way of Community Based Waste Treatment (CBWT) to become energy that does not require preliminary segregation, no leachate, and no strong odor during the process. The output of the TOSS is a pellet or briquette as biocoal that has a higher level of usage, compared to other waste treatment products such as fertilizers or other recycled products. TOSS began in the academic field in the era of 2015-2016 via the initiative to empower local people to manage and own their energy, particularly electricity by using renewable energy available in the community. This idea is called "Listrik Kerakyatan" or community-based electricity. Such renewable energy includes sun, wind, and waste however the perpetual waste problems drove this idea to focus more on waste to energy, which finally shows that TOSS is the most suitable way of waste to energy solution (Legino, 2017, Solving; Legino, 2019, Listrik Kerakyatan; Legino 2019, Simulation).

After passing the pilot stage, TOSS is applied for the first time, at Klungkung, Bali (see figure 4), and TOSS has achieved "Proper Emas", a prestigious environmental care award for PT Indonesia Power and a top 40 public service innovation for Klungkung district. Upon successful implementation, TOSS then had been replicated further in several areas as shown in Figure 4.

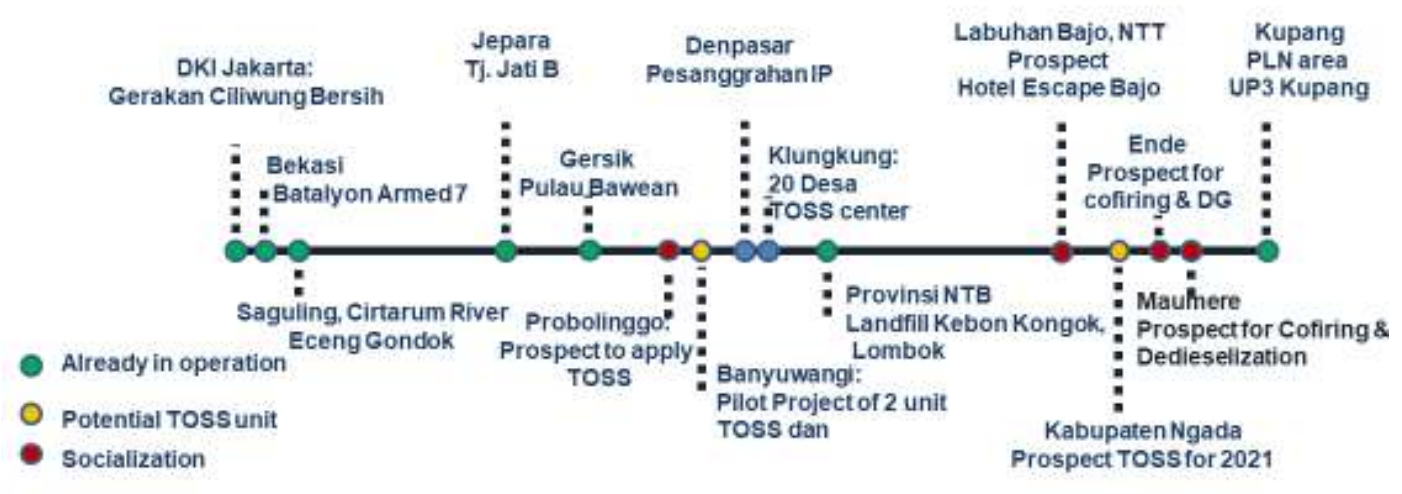

Figure 4. Multi cases areas of study of TOSS in various stages of activities

TOSS has been implemented at the PLN Indonesia Power, Denpasar Office and more than 5 (five) villages and communities in Klungkung District and Badung, Bali. The pilot projects have been conducted successfully by STT PLN and the community of Pondok Kopi, DKI Jakarta; PLN 
Tanjung Jati B Coal Fired Power Plant at Jepara, Central Java; by PT Adaro Grup at Tabalong, Kalimantan Selatan; by PLN UP3 Kupang at Nusa Tenggara Timur; by Batalyon Armed 7 with PLN support in Bekasi, West Java; and by the river community, Gerakan Ciliwung Bersih, in DKI Jakarta. The ultimate and proximate testing for more than 40 domestic waste and various biomass samples have been conducted in various laboratories including Tekmira, Sucofindo, and Geotech (Legino, 2020).

\section{Financial indicators}

The financial indicator of TOSS as community based waste treatment to become pellet is initially indicated by Legino as specific cost per ton of waste. The data is initially indicated from the first pilot project of TOSS at Pondok Kopi and Duri kosambi areas, DKI Jakarta Provence. For instance, the capital expenditure for 3 ton of waste treatment is USD 74,360 equal to and the operational expenditure is USD 14,435 (Legino, 2017). However, after conducting further pilot projects, the investment and operational costs for TOSS unit have been changed and for this study, will use modified information of the latest case studies as shown in Table 1 and Table 2 (Legino,2020). The calculation is based on the following specific costs: Preparation cost $/ \mathrm{m}^{2}$ (IDR 200,000), civil cost $/ \mathrm{m}^{2}$ (IDR 1,500,000), operator salary/month (IDR 3,000,000), training /person (IDR $1,500,000)$, spare parts and material (10\% of operational cost), bamboo box for 1 ton of waste (IDR 1000,000, energy cost/ton of waste (IDR 50,000), other facilities/ton of waste (IDR $2,500,000$ ), daily overhead/ton of waste (IDR 20,000).

Table 1. Investment cost for 3 ton of Waste CBWT

\begin{tabular}{ll}
\hline Volume (Ton/day) & 3 \\
Area needed (m2) & 100 \\
Preparation work* & $20,000,000$ \\
Civil work** & $150,000,000$ \\
Training (1,5jt/person) & $15,000,000$ \\
Bamboo boxeu (IDR 1 M/unit) & $10,000,000$ \\
Waste crushers & $90,000,000$ \\
Hammer mills & $80,000,000$ \\
Pellet machines & $119,000,000$ \\
Other facilities (IDR 3.5M/ton) & $12,000,000$ \\
Stoves (@IDR400.000u) & $1,200,000$ \\
Total Investment cost (IDR) & $497,200,000$ \\
\hline
\end{tabular}




\begin{tabular}{ll} 
Table 2. Operational cost for 3 ton of waste CBWT & \\
\hline Volume (Ton/day) & 3 \\
Operator slary per year (IDR) & $72,000,000$ \\
Overhead & $21,900,000$ \\
Material sp part TOSS & $28,900,000$ \\
OM Services TOSS & $23,120,000$ \\
Bioactivator & $43,800,000$ \\
Transportation & $36,500,000$ \\
Energy cost & $54,750,000$ \\
Land leasing & - \\
Total Operational Exepnditure (IDR) & $280,970,003$
\end{tabular}

\section{Results and Discussion}

This study will assume that the populations of the city is 10 million people to illustrate the size population of Jakarta City. and the IRR of $11 \%$, higher than the assumed discount factor of $9 \%$, to represent the low bank interest dedicated for Small Enterprise, and for simplification, no tax was applied. The land will be provided by the city government or communities with other cost parameters assumed as mentioned in Table 3.

There are 3 (three) scenarios that will be run in this simulation to determine the amount of Tipping Fee:

1. The required Tipping fee with various capital subsidies such as for equipment, with the pellet price of IDR 500 per kg, worker salary of IDR 3,000,000.

2. The required Tipping fee with various worker salaries, no capital subsidy, and the pellet price of IDR $500 / \mathrm{kg}$

3. The required Tipping Fee with various prices of pellet, 50\% capital subsidy, and worker salary of IDR 3,000,000

Under the first scenario, the pellet price is fixed, IDR $500 / \mathrm{kg}$, to represent the determined price of National Electricity Company as a buyer. The monthly salary is also fixed IDR 3,000,000 to represent the minimum regional wages of Jakarta. In other to maintain small business sustainability, the IRR should be kept above the interest rate, in this case around 11\%. Therefore, there should other incomes scheme as input variables. In this scenario, the first input variable is capital subsidy such as CSR from sponsor or machines from local government and the second input variable is the amount of Tipping Fee, the amount of which depends on local government affordability.

For instance, if there is no capital subsidy, the local government should pay a Tipping Fee of IDR 266,301 per ton of waste to the small business for waste treatment services. The Tipping Fee can be down to IDR201,205 if there is a 75\% capital subsidy. In case the local government can not pay the tipping fee, then the household $(\mathrm{HH})$ and other polluters have to pay the fee. For example, if the pellet price is set to IDR 600 per $\mathrm{kg}$, then the local government should pay a Tipping fee of IDR 175,068 equivalent to HH contribution of IDR 35,500 per HH. The result of the simulation for Scenario 1 is shown on table 3 . 
Table 3. Simulation result of Scenario 1 with input variables: capital subsidy and Tipping Fee Scenario 1: Pellet pr IDR 500/kg, Various Cap. subsidy, Monthly salary IDR 3.000.000, and IRR $11 \%$

\begin{tabular}{|c|c|c|c|c|}
\hline Capital Subsidy & Revenue & IRR & $\begin{array}{l}\text { Tip. } \\
\text { (IDR) }\end{array}$ & HHS. Ff/M (IDR) \\
\hline $0 \%$ & $428,475,000$ & $11.1 \%$ & 266,301 & 54,000 \\
\hline $25 \%$ & $358,000,000$ & $10.3 \%$ & 231,781 & 47,000 \\
\hline $50 \%$ & $357,000,000$ & $10.9 \%$ & 201,205 & 40,800 \\
\hline $75 \%$ & $321,015,000$ & $10.8 \%$ & 168,164 & 34,200 \\
\hline $100 \%$ & $356,646,375$ & $10.9 \%$ & 101,096 & 20,500 \\
\hline
\end{tabular}

Similarly, table 4 shows the result of Scenario 2, in which input variables are the price of pellet and Tipping Fee.

Table 4. Simulation result of Scenario 2: input variables: pellet price and tipping fee/HH contribution

\begin{tabular}{|c|c|c|c|c|c|c|}
\hline \multicolumn{7}{|c|}{ Scenario 3: Various Pellet Price, 50\% Cap. subsidy, Monthly salary IDR 3.000.000, and IRR 11\% } \\
\hline $\begin{array}{l}\text { Pellet } \\
\text { (IDR) }\end{array}$ & $\mathrm{pr} / \mathrm{ton}$ & $\begin{array}{ll}\text { Ann. } & \text { Revenue } \\
\text { (IDR) } & \end{array}$ & IRR & $\begin{array}{l}\text { Tip. } \\
\text { (IDR) }\end{array}$ & Fee/ton & HHS. Ff/M (IDR) \\
\hline 300,000 & & $357,525,000$ & $11,1 \%$ & 251,507 & & 51,000 \\
\hline 500,000 & & $358,275,000$ & $11,3 \%$ & 202,192 & & 41,000 \\
\hline 600,000 & & $355,950,000$ & $11,0 \%$ & 175,068 & & 35,800 \\
\hline 750,000 & & $356,512,500$ & $11,0 \%$ & 138,082 & & 28,000 \\
\hline 900,000 & & $356,646,375$ & $10,9 \%$ & 101,096 & & 20,500 \\
\hline
\end{tabular}

\section{Calculation}

To answer the first question about what is the cost and under what conditions to make the river clean? In this case, the required condition is to shift the waste treatment from landfill to CBWT and the cost parameters such as workers salary, capital subsidy, land lease, and household fee can be exercised with various values using the following financial formula for 3 ton per day of waste. The simulation will be used to determine the various combination of the required tipping fee for cleaning the river by using CBWT that still provides a good return (IRR>Discount Factor) for the small business that treats the waste in the community (Legino et.al., 2017; Legino et al., 2019).

The following formula is developed to answer the research questions about the required cost of the proposed model and the time required to apply the proposed waste management to make the rivers crossing the city

Amount of Municipal Waste (Wm)

$\mathrm{W}_{\mathrm{M}}=\mathrm{f}_{\mathrm{pw}} \mathrm{x}$; ; where $\mathrm{P}$ is the population of the city and $\mathrm{f}_{\mathrm{PW}}$ is the average waste produced by one man

$\mathrm{W}_{\mathrm{M}}=\mathrm{W}_{\mathrm{S}}+\mathrm{W}_{\mathrm{L}}+\mathrm{W}_{\mathrm{O}}+\mathrm{W}_{\mathrm{R}}$

where $\mathrm{W}_{\mathrm{S}}$ is waste portion processing at its source (in\%); $\mathrm{W}_{\mathrm{L}}$ is waste processing at the landfill (in\%);

Wo is waste scattered at other places (in\%); and $\mathrm{W}_{\mathrm{R}}$ is waste throwing to the river (in\%)

The waste amount that will be converted into biocoal are the sum of those treated at the communities (Ws) and the rest that should be treated from and along the river riparian (Wr). The total units of TOSS with the capacity of 3 ton is $n=(W s+W r) / 3$

The total cost of investment (CT) 
$\mathrm{C}_{\mathrm{T}}=\mathrm{n} \times \mathrm{I}_{\mathrm{t}} ;$ where the number of units required: $\mathrm{n}=\left(\mathrm{W}_{\mathrm{R}}+\mathrm{Ws}\right) / 3$ and

$\mathrm{I}_{\mathrm{t}}$ : the capital expenditure

The total annual operational cost $(\mathrm{Ot})$ :

$\mathrm{O}_{\mathrm{T}}=\mathrm{n} \times \mathrm{O}_{\mathrm{t}}$; where $\mathrm{n}=\left(\mathrm{Ws}+\mathrm{W}_{\mathrm{R}}\right) / 3$ and

$\mathrm{O}_{\mathrm{t}}$ : operational expenditure

The annual revenue is calculated by the assumption that the TOSS business operator will get two sources of revenue. The first revenue is taken by selling pellet to PLN (Indonesia State-Owned Enterprise for Electricity) for cofiring purposes with the price $85 \%$ of coal price with equivalent calorific value. The second income is taken from the tipping fee (TF) per ton of waste, from the city government.

The total revenue (TR):

$\mathrm{TR}=\left(\mathrm{W}_{\mathrm{R}}+\mathrm{Ws}\right) \times \mathrm{TF}+\left(\mathrm{W}_{\mathrm{R}}+\mathrm{Ws}\right) / 3 \times \mathrm{p} ; \mathrm{W}_{\mathrm{M}}=\mathrm{W}_{\mathrm{S}}+\mathrm{W}_{\mathrm{L}}+\mathrm{W}_{\mathrm{O}}+\mathrm{W}_{\mathrm{R}} ;$

Where: $\mathrm{W}_{\mathrm{R}}$ is waste amount to the river (ton); $\mathrm{W}_{\mathrm{R}}$ is waste amount treated at its sources (ton); $\mathrm{TF}$ is

tipping fee (IDR), $\mathrm{p}$ is the pellet price

The second research question about how and how long that the proposed study can be expected to clean the rivers around Jakarta?, and it will be answered as follows. The way to clean the river is by empowering small and medium businesses to run the waste treatment services at its sources or communities and gradually shifting the waste treatment from centralized at the landfill to the each community as the sources of waste. This approached is adopted the commutative law of algebra depicted by Legino as the option to solve the large-scale dilemma of electricity. Legino asserts the concept by illustration that $1000 \times 1=1 \times 1000$, means that building a complicated large-scale power plant of $1000 \mathrm{MW}$ can be altered by building 1000 units of smal scale 1 MW, which are easier and less problematics. In another study, Legino proposes to empower Small and Medium Enterprises to run such small-scale business that are scattered around the country (Legino \& Arianto, 2017).

By distributing the waste treatment activities to its source, then the expected time to attain the clean river " $\mathrm{t}$," the amount of $\mathrm{W}_{\mathrm{R}}$ and $\mathrm{W}_{\mathrm{S}}$ should be minimum and the waste that will be treated at the landfill should be maintained at the certain amount that cannot exceed the landfill capacity. How long it takes to clean the rivers by applying the CBWT or TOSS is depended upon the intention of the city government and the budget availability that can be allocated for the program as will be an exercise in this study.

Assumed that the population of the Jakarta city, $\mathrm{P}=10,000,000$ people, and every person produces $0,5 \mathrm{~kg}$ of waste per day on average, and assumed that before TOSS was applied $\mathrm{W}_{\mathrm{L}}=60 \%$, $\mathrm{W}_{S}=10 \%, \mathrm{~W}_{\mathrm{R}}=20 \%$, and $\mathrm{W}_{0}=10 \%$; where $\mathrm{W}_{S}$ is waste portion processing at its source (in $\%$ ); $\mathrm{W}_{\mathrm{L}}$ is waste processing at the landfill (in\%); Wo is waste scattered at other places (in\%); and $\mathrm{W}_{\mathrm{R}}$ is waste thrown into the river (in\%).

$$
\begin{aligned}
& \mathrm{f}_{\mathrm{pw}}=0,5 \\
& \mathrm{~W}_{\mathrm{M}}=\mathrm{f}_{\mathrm{pw}} \times \mathrm{P}=0,6 * 10,000,000=6,000,000 \mathrm{~kg}=6,000 \text { ton of waste } \\
& \mathrm{W}_{\mathrm{M}}=\mathrm{W}_{\mathrm{S}}+\mathrm{W}_{\mathrm{L}}+\mathrm{W}_{\mathrm{O}}+\mathrm{W}_{\mathrm{R}}=6000 \text { ton } / \text { day, then } \\
& \mathrm{W}_{\mathrm{L}}=60 \% \times 6000=3,600 \text { tpd, } \mathrm{W}_{\mathrm{S}}=10 \% \times 6,000=600 \text { tpd, } \\
& \mathrm{W}_{\mathrm{R}}=20 \% \times 6,000=1,200 \text { tpd, and } \mathrm{W}_{\mathrm{O}}=10 \% \times 6000=600 \text { tpd. }
\end{aligned}
$$

To get a manageable waste that goes to the river, then the amount of waste to the river should be less than $5 \%$ and waste to another public place is less than $10 \%$. If the maximum amount of waste that can be treated continuously at landfill is 1000 ton per day, then:

$\mathrm{W}_{\mathrm{L}}=1,000$, and 


$$
\begin{aligned}
& W_{R}=5 \% \times 6,000 \text { ton } / \text { day }=300 \text { ton/day } \\
& W_{O}=10 \% \times 6,000 \text { ton/day }=600 \text { ton per day and } \\
& W_{S}=(6000-1000-300-600) \text { ton/day }=4,100 \text { ton/day }
\end{aligned}
$$

The waste will be treated by TOSS model at Wr and Ws will be $4100+300=4,400$ ton/day. The number of TOSS unit with 3 ton/day capacity required: $n=4,400 / 3=1,467$ units (rounded) The total investment cost required, $C_{\mathrm{T}}=\mathrm{n} \times$ It $=1,467 \times$ IDR 497,200,000 $=$ IDR 729,4 Billion The total annual operational cost required, $\mathrm{O}_{\mathrm{T}}=\mathrm{n} \times \mathrm{Ot}=1467 \times$ IDR 280,970 $=$ IDR 412,2 Billion

CBWT is designed to educate people and its local Small Business to treat their own wastes in their communities and it should become their need and has to be financially attractive. Therefore, the profit has to be secured by keeping the IRR higher than the bank interest, by using other controllable cost components and revenue sources as variables. For example, since by rule, the pellet price is fixed, IDR 500/kg and a monthly salary amount should comply to the minimum regional wages, the possible controlable financial components are capital subsidy such as CSR from sponsor or machines from local government and the revenue amount of Tipping Fee that can be decided by local government. If the monthly salary is IDR 3 millions, then the local government should pay the Tipping Fee of IDR 266,301 per ton of waste, but it can be altered also by household contribution.

The calculation shows that to reduce the amount of waste to landfill from 3,600 ton/ day $(60 \%)$ to 1,000 ton/day, there should be built 1,467 Toss unit of 3 ton/day to manage 4,400 ton of waste/day. The total budget required for investment is IDR 729,4 Billion that can be spread into three concecutive years if for instance, the local government annual budget availability is only IDR 250 Billions. It means that the required time to solve the waste problem is 3 (three) years. The annual cost operation total is IDR 412,2 Billion, but it becomes the obligation of the company that run this waste treatment, which may get potential profit as illustrated in table 3 and table 4 .

The TOSS model is basically created for local people empowerment to participate in waste service business through the Small and Medium Enterprise (SME) (Legino, 2017). Therefore, in the financial model, the profitability is given by attractive return as indicated by IRR $>$ Interest or discount factor for all scenarios. In order to make the business of these SMEs sustained, the city government should prepare the budget for paying Tipping Fee (TF), the amount of which depends on a selected scenario as illustrated in the simulation. For instance, the city government intends to clean all rivers in Jakarta in one year, but the affordable annual budget allocated for Tipping Fee to treat 6,000 ton of waste per day is IDR 450 Billion. It means that the Tipping Fee is below IDR 200,000 , and if the most reasonable pellet price is IDR 500,000 per ton, then the scenario 2 can be chosen by the effort to get $75 \%$ capital subsidy. However, if the available annual budget is only one half, then the program will be completed in two years for the same scenario and other conditions can be exercised using similar calculation.

Community Based Waste Treatment (CBWT) potentially renders economical benefit as its model is designed to make sustainable business for Small and Medium Enterprise (SME). It also creates employment opportunities and increases the use of local content material and equipment in addition to environmental benefit as it can reduce the green house gasses emission from landfill and fossil substitution (Legino 2017, solving; simulation; Legino 2019, waste; attainment; reducing Legino 2020, Listrik Kerakyatan; Opportunities).

Various study reported that the TOSS model as CBWT may potentially profitable as reflected by Internal Rate of Return (IRR) 11\% to 20\%, higher than the common interest rate for the small business of 9\% (Legino, 2017, Simulation; Legino 2019; Waste). Besides the financial benefit for small and medium enterprises, CBWT-TOSS provides also economic benefit for the nation because it is attractive for new business creation particularly for those of Small and Medium Enterprises. The advantage of TOSS is that the level of consumption of pellet as the end product of TOSS will 
be much higher than fertilizer that is currently produced by many "Bank Sampah," (Brand name of Small-scale Waste Services Business).

TOSS will give a new product line for small and medium enterprises including thousands of current business model of "Bank Sampah" because there will always be demand for bio-coal briquette as fuel. While the demand of composting fertilizers as conventional product of "Bank Sampah" will be limited. TOSS will also promote the government policy to maximize the use of local material and man power for renewable energy development because it has very little dependency to the import material and expertise (Legino, 2017; Legino, 2019; Legino, 2020). Economic benefit is also asserted by Legino in his presentation at MICES 2020 conference Medan, Indonesia as shown in Figure $5(2020,45)$.

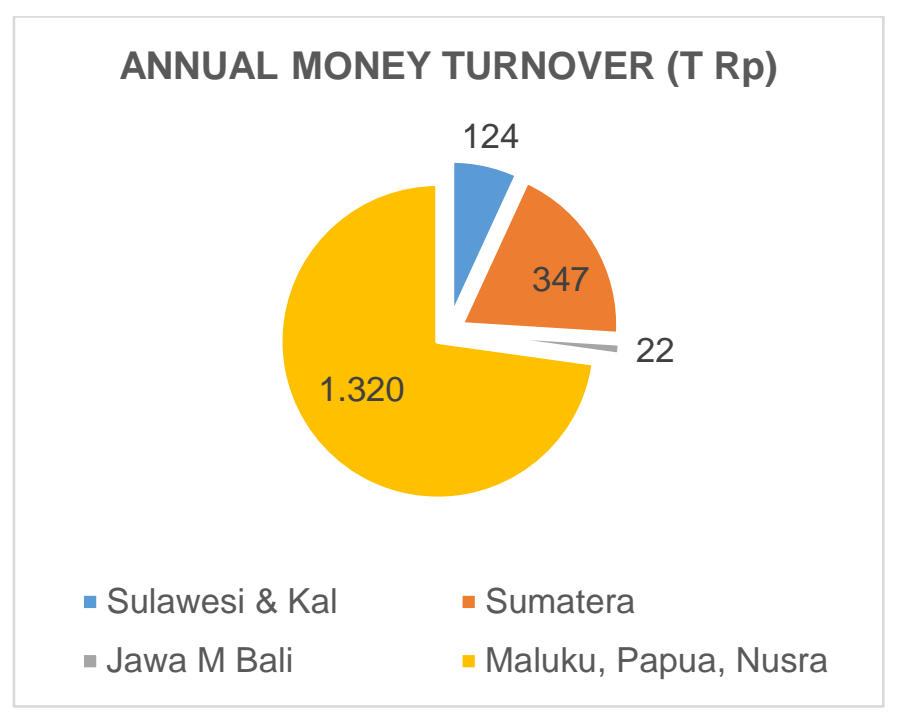

Figure 5. Annual money turnover from TOSS CBWT model

In the same study, Legino (2017) also depicted that CBWT thru the TOSS model potentially creates employment opportunity as it may attract UMKM or small and medium enterprise (SME) to run this ecofriendly business since it may potentially offer good return both from selling the product and getting the service fee while providing working opportunity at the same time. One TOSS unit of 3 ton of waste will employ at least 3 direct and 2 indirect workers, means that if there will be 1467 TOSS units as resulted in simulation, it will potentially provide working opportunities to more than 7,000 people. Legino also depicted in another study that the briquette fuel as the product of CBWT can replace the diesel fuel so that the rural cost of electricity will be cheaper compare to the cost of installing Medium Voltage lines. In other words, the attainment to serve electricity to all people in the nation can be achieved faster and cheaper (Legino, 2020). The social benefit is also presented by Legino that TOSS may potentially creates employment opportunities across the nation as shown in figure $6(2020,46)$. 


\section{EMPLOYMENT POTENSIAL}

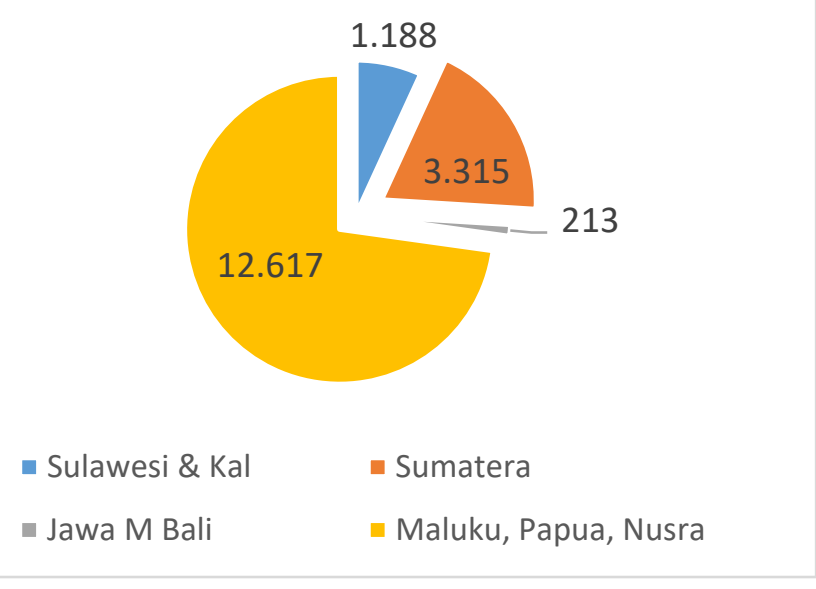

Figure 6. Employment opportunity of CBWT-TOSS model

CBWT-TOSS is beneficial for environment since the program will promote a simple way of waste treatment which is friendly to the environment and can convert the piles of dirty waste in the temporary deposit by placing it into the array of bamboo boxes with no leachate and odor. The main purpose of CBWT is to avoid waste processing at landfill which has limited space and create pollution from transportation of waste to landfill. According to the US Environment Protection Agency (EPA), the treatment of any ton of waste at its source rather than at the landfill can reduce 2.94 ton of $\mathrm{CO}_{2 \mathrm{e}}$. In addition, any pound of coal substitution by CBWT product, the Carbon equivalent reduction will be added by $9.8 \times 10^{-4}$ ton of $\mathrm{CO}_{2 \mathrm{e}}$. if the briquette as CBWT product can be used to substitute coal (EPA, 2019).

Such a potential benefit could possibly change the ignorance mindset about environment to pay more care in keeping their communities clean from any wastes. Such ecosystem sustainability can be achieved by treating waste at its source as a part of eco-riparian management that can minimize the practice of throwing waste into the river or public space. While the waste that has been thrown into the river will be lifted and brought to the closest TOSS unit that will be built along the river. If more people in the river communities join the program, the risk of routine flood in the city can be decreased.

Specifically, Legino presented at MICES 2020 conference that "potential Carbon Capitalization is around 80 thousand tons carbon equivalent annually, and with assumption of USD 1,0 per ton carbon means aroung 2,200 trillion Rupiah annually " $(2020,47)$ education as a solution to the impact of the industrial era 4.0. required entrepreneur education. The concept of entrepreneurial education will create creative and innovative children who able to overcome the obstacles in the future. Moravec states that industry 4.0 requires the education to build individual innovation practices and student empowerment teams to produce innovation (Sarikaya \& Coskun, 2019). Schools are educational institutions designed for the development of human potentials. Also, the purpose of education is to improve the quality of human resources with the anticipation of producing superior and characterized human beings, raised through the affirmation of each activity that is integrated into entrepreneurship-based learning in school

Ningrum's opinion (2017) reported entrepreneurship as a soul, attitude, ability to create something new, valuable and useful for personal consumption and others, while entrepreneurs are skilled personnel in the aspect of developing personal businesses and taking advantage of opportunities, to improve their lives. Moreover, Nurseto (2010) established that efforts needed to instill the required entrepreneurship for teachers ought not to be limited to master the concepts, but also have the ability to perform the related activities. These include the application of all existing conceptions 
The plans towards learning conducted at Mata Najwa Kindergarten which involved the application of entrepreneurship activities in early childhood, including several learning components, encompassing: 1) the objectives; 2) materials; 3) educators; 4) students; and 5) strategies (Sofino, 2017). This is followed by the inculcation of entrepreneurial values, performed in a series of activities that are initiated with planning, learning, implementing and evaluating. Sani and Yunus (2018) in Malaysia showed the need to relate the results of research on teaching design or planning to one another and not to a specific subject. Furthermore, the information required is centered on the objective learning content, approaches, methods used, the imparting techniques and assessment design of the teachers' teaching and learning outcomes. These are needed to play the role of an evaluation material, which ought to be performed and added on instances where there are deficiencies. The cooking class is innovative programs in preschool children. These are usually conducted to promote healthy eating behaviors, attained by providing the knowledge on basic nutrition, food selection, menu planning, time-saving tips in the kitchen and food preparation skills to parents and caregivers (Condrasky et al., 2006).

This is also significantly increased their willingness to explore fruits and vegetables, as reported by parents. Also, the effectiveness of cooking on children's food-related preferences, attitude and behaviors is promoted (Hersch et al., 2014). The results and discussions stipulated that the values of entrepreneurship need to be internalized in students include independent, creativity, the dare to take risks, action-oriented.

\section{Conclusion}

The proposed program thru the implementation of CBWT-TOSS is potential for scaling up and replication since TOSS model does not require any special skill to operate and it also provides simple waste segregation because the unsorted plastic and alike can be sorted later after the waste is dry and no more odor after mechanical biological treatment process. Hence, it can be easily learned and replicated or scaled up with no gender issue. The simplicity of the technology invites more business entities to participate and implement the same system in their area.

As shown in the result of simulation, the amount of waste throw into the river may be reduced from 1200 ton per day to the manageable amount of 300 ton per day by applying CBWT. Therefor this Program will free the largest river in Jakarta, Ciliwung and its riparian from waste which will result in a clean river. More spaces will be available across the riparian and some can be developed as public places such as the one on Kalijodo River. In the end, a clean river will provide many benefits to its communities, one which is a creation of a friendly environment that is safe for children to play and explore.

The program is also render legal contribution that may be benefecial to reduce the risk of flood due to the many waste piled inside the river will be resulted if the government declare a national policy that there should be TOSS units applied along the River Riparians. The implementation of this program should also encourage the government to establish regulation that motivate other communities to deploy this program in their own area, which in turn would aid in solving the country's perpetual waste issues.

\section{Acknowledgment}

Thanks and appreciations to our CBWT team lead by Arief Noerhidayat and other parties who have carried out the pilot projects and implementation of TOSS-CBWT in more than 15 loacations across the nation. Appreciation also to Mr. Sonny Djatnika S who invented strong dedication to develop TOSS as a waste and energy solution 


\section{References}

EPA. (2020). Inventory of U.S. greenhouse gas emission and sinks:1990-2018. Washington, DC. US: Environmental Protection Agency.

EPA (2019). Waste Reduction Model (WARM), Version 15. U.S. Environmental Protection Agency.

Fei, F., Wen, Z., Huang, S., Clercq, D. D. (2018). Mechanical biological treatment of municipal solid waste: Energy efficiency, environmental impact and economic feasibility analysis. Journal of Cleaner Production, 178, 1-8. Doi: 10.1016/j.jclepro.2018.01.060

Kholil, A., Budiaman, Mirtawati, Amaningsih, A., \& Jumhu. (2018). Waste Management Based on 3R in Mutiara Waste Banks Bekasi City Indonesia. World Environment, 8(3), 71-76

Legino, S. (2020). The Opportunities and Challenges of Waste to Energy Development in Indonesia. The Medan International Conference on Energy and Sustainability 2020 (MICES 2020). Energy, Covid-19, and The Changing World. 100 ${ }^{\text {th }}$ itb-iaitbsumut. Medan October, 27-28, 2020.

Legino, S., Arianto, R., \& Pasra, N. (2019). The attainment of 100 percent electrification ratio in the archipelago of Indonesia by people way electricity initiative. Journal of Physics Conference Series, 1282, 012057. Doi:10.1088/1742-6596/1282/1/012057

Legino, S., Hidayawanti, R., Putra, I. S., \& Pribadi, A. (2019). Reducing coal consumption by people empowerment using local waste processing unit. Journal of Physics Conference Series 1217, 012028. DOI:10.1088/1742-6596/1217/1/012028

Legino, S., Hidayawanti, R., \& Wirantika, I. (2019). Waste as fastest cycle of renewable energy sources through TOSS Model. Journal of Physics: Conference Series, 1282, 012041. DOI:10.1088/1742-6596/1282/1/012041

Legino, S., Wirantina, I., Hidayawanti, R., \& Sangadji, I. (2017). Simulation of economic effect on electricity democracy based on clean energy at UMKM'S IPP in Indonesia. CCESG Conference.

Legino, S., \& Arianto, R. (2017). Solving large scale unit dilemma in electricity system by applying commutative law, Icompac.

Munnich, K., Mahler, C. F., \& Fricke, K. (2006). Pilot project of mechanical-biological treatment of waste in Brazil. Waste Management, 26(2), 1-6.

Raharjo, S., Junaidi, N. E., Bachtiar, V. S., Ruslinda, Y., Rachman, I., \& Matsumoto, T. (2016). Development of community-based waste recycling (garbage bank and 3R waste treatment facility) for mitigating greenhouse gas emissions in Padang City, Indonesia. Management and Innovation Technology International Conference (MITicon), 2016, pp. MIT-8-MIT-12,

Sistem Informasi Sampah Nasional. (2020). (https://sipsn.menlhk.go.id/sipsn/).

Sucahyo, H. N. (2019). Pencemaran sungai yang kian terabaikan. https://www.voaindonesia.com/a/pencemaran-sungai-yang-kianterabaikan/5056275.html

Supriadi, L., Sonny, D. S. D., \& Arief, N. H. (2019). Listrik kerakyatan, community-based electricity: a simple solution for energy and waste crisis. Jakarta, Languaged Development Center, STT PLN

Supriadi, A, T., Legino, S., Purwanto, Y. S., Wulandari, D. A., Jatnika, H. (2020). Implementing triple helix through Listrik Kerakyatan initiative: community-based energy from waste. Journal of Physics: Conference Series, 1282, 012094

Tambone, F., Scaglia, B., Scotti, S., \& Adani, F. (2011). Effects of biodrying process on municipal solid waste properties. /8/1 Bioresource technology, 201/8/1 Elsevier

Tata Kelola Persampahan di Indonesia. (2011). Rangkuman Hasil Webinar Teknologi Persampahan Juni-November 2020. Dir Jen Pengelolaan Sampah, Limbah dan B3 KLHK, Dirjen Cipta Karya Kem. PUPR, Yayasan Dana Mitra Lingkungan, Cetakan Pertama Maret 2021

Tom, A. P., Pawels, R., \& Harridas, A. (2016). Biodrying process: A sustainable technology for treatment of municipal solid waste with high moisture content. Waste Management, 49, 64-72.https://doi.org/10.1016/j.wasman.2016.01.004

Velis, C. A., Longhurst, P. J., Drew, G. H., Smiths, R., \& Pollard, J. T. (2009). Biodrying for mechanical-biological treatment of wastes: A review of process science and engineering. Bioresource Technology, 100(11), 2747-2761. 